\title{
Correlation of Self-Efficacy with Decision Making Continuing Studies in College Students at Islamic Based Universities
}

\author{
Defriyanto, lip Sugiharta
}

Universitas Islam Negeri Raden Intan Lampung Indonesia
defriyanto@radenintan.ac.id, iipsugiharta@ radenintan.ac.id

Submitted: 2020-03-26, Revised: 2020-04-13, Accepted: 2020-05-22

\begin{abstract}
Decision making requires courage and confidence from individuals to be able to make decisions even though it has consequences where self-efficacy is a factor because people believe in their ability to make decisions. This study aims to determine the correlation of self-efficacy with decision making continuing studies in college students at Islamic based universities. The study population was college students of the Raden Intan State Islamic University, Lampung, with a random sampling method. The total sample of 504 college students. The instruments in this study were the scale of self-efficacy, and the scale of decision making. Data analysis using the Karl Spearman correlation test was assisted by SPSS software for Windows 23 . The correlation score from the results of the study was 0.628 which showed a strong relationship between self-efficacy and respondent decision making so that the Self-Efficacy of Raden Intan college students of the State Islamic University has strong in making decisions in continuing their studies
\end{abstract}

Keywords: Confidence; Decision Making; Self-Efficacy

\section{Introduction}

Self-efficacy is the confidence or ability to perform tasks on individual perceptionsself-efficacy as a feeling of adequacy, efficiency, and ability to overcome life's problems. Selfefficacy affects the choice of action to be taken, the amount of effort, and resilience in dealing with obstacles or difficulties. Also, the effect of self-efficacy has much influence on education, because it can influence people's choices (Schunk \& DiBenedetto, 2016). Humans are not enough just to have knowledge and skills, and they must also have the self-confidence that they can succeed in doing something that is needed, accompanied by exceptional circumstances (Bandura, 1977, 1997; Rustika, 2012).

Self-efficacy has an impact on motivation studies and achievement in academic settings. Academic self-efficacy is the single strongest predictor of student achievement and performance (Asakereh \& Yousofi, 2018). Student academic self-efficacy is a worthwhile goal for every educator, so the main objective of formal education must be to equip students with the intellectual tools, efficacy beliefs, and intrinsic interests needed to educate themselves. Reliable and robust opinions will become more critical for individuals as they strive to control learning control progressively (Liu, Dong, Chiclana, Cabrerizo, \& Herrera-Viedma, 2017). Students, parents, and educators must realize that lack of self-confidence can weaken the increase in self-efficacy in making further study decisions and developing skills in education(Guan et al., 2016). This is supported by research that says that the identification of individuals on the status of achievement identity will have a positive impact on the self-efficacy of continuing study decisions (Lent, Ezeofor, Morrison, Penn, \& Ireland, 2016).

Besides, self-efficacy and decision making have a negative influence on career decision doubts in first-year students (Frazier, Bendixen, \& Hoskins, 2019). Therefore self-efficacy in decision making is so important for students that, when choosing a university, they do not feel wrong or even fail because it will have an impact on their future careers. Decision making is an individual thought process to integrate self-knowledge and work knowledge to arrive at job choices that might be seen as career development to be faced (Gati, Levin, \& Landman-Tal, 2019). Further study decision making should be done since becoming a student so that later 
when it becomes a college student, it is easy to determine the next steps after graduating from college. With career decision making, students can develop several strategies and be ready to get involved in work competition.

In general, college students have thought and designed the future that they will face. When becoming college students, they must be able to develop themselves optimally so that they are ready and able to meet the world of work. College students are expected to be able to recognize their potential and interests and talents to be able to facilitate career planning to career decision making in the future. For this reason, ethical decision-making ability is needed to get an education and career that is in line with the potential possessed and desired.

Besides, self-confidence is needed to undergo a thing, because it is necessary so that someone does not give up in facing problems that arise after making a decision (Kirdök \& Harman, 2018). In choosing or determining the continuation of study and preparing for a future career, a student must have a next picture of the career field that is the basis for setting goals, planning and making the right decision by choosing one alternative job from a variety of tasks, considering the travel time lectures, and choose the correct study continuation. This is supported by research that says, when someone has a low picture or plan then in making study decisions, it will not be useful because it is not by what is expected and the ideals or not by future goals (Negru-Subtirica \& Pop, 2016).

The existence of self-efficacy in decision making can minimize the delay in completing tasks related to the career to be achieved, believe in his ability to learn to achieve goals and overcome obstacles, knowing the competencies needed to make a career, gaining a clear view of self including advantages and shortcomings, and can be responsive to various situations and find solutions to existing obstacles (Chiesa, Massei, \& Guglielmi, 2016) . This is in line with research that states, that the right decision making, individuals will be more independent, making job choices that are by their interests and abilities, ability to use methods, principles of decision making for solving problems, including choosing education and work (Whiston, Li, Mitts, \& Wright, 2017).

Self-efficacy and the decision to continue education at tertiary institutions are essential, considering that tertiary institutions are a platform for students to develop abilities and deepen the knowledge that must be equipped with self-understanding, self-ability, and have confidence in the future career success. Qualified educational institutions for the younger generation are a reason for students in choosing tertiary institutions. Raden Intan State Islamic University is an Islamic based university, which in its scope, is closely related to spiritual and religious motivations. Religion and spirituality have a positive influence on cognitive and individual behavior(Sari, 2020). This is because there is friendship with fellow believers so that it can provide social support that leads to increased happiness and mental health so that it will significantly improve the ability to learn as well as performance. About self-efficacy and decision making, students are expected to have confidence and ability as college students who can improve their overall skills, especially in terms of spirituality, this is important because norms, moral values, and laws originating from Islamic religion are the basis of spiritual motivation influential in future learning and careers.

The purpose of this study is to determine the level of self-efficacy and its relationship to decision making in continuing education at college students at Islamic-based universities. This research is expected to be able to provide reference materials for Islamic-based relating to self-efficacy and decision-making to pursue education so that institutions can take action to offer solutions to college students in making the right decisions in continuing education.

\section{Methods}

This research is a quantitative study with a type of correlational research that aims to determine the correlation of self-efficacy with sustainable study decision making in college 
students at Islamic-based universities. The population of this research is college students of the Raden Intan Lampung Islamic State University Lampung, with a random sampling method. The total sample of 504 college students, consisting of college students from the Tarbiyah and Teaching faculties, the Ushuluddin faculty and Religious Studies, the Sharia faculty, the Da'wah Faculty, the Faculty of Islamic Business Economics, 105 male respondents and 399 female respondents within the Raden Intan Lampung Islamic State University.

The instruments in this study were the self-efficacy scale and decision-making scale. The self-efficacy scale was adapted from the general self-efficacy scale (GSE) by Born, Schwarzer \& Jerussalem (1995), consisting of three aspects and 10 statement items, each item consisting of favorable and unfavorable items. The scale of decision making using the theory of Jannis and Leon Mann (1977) has five aspects composed of 32 items, each item consisting of favorable and unfavorable items. The instrument was tested for validity and reliability testing (Alpha Cronbach). Data analysis techniques using the Karl Spearman correlation test aided by SPSS software for Windows 23 .

\section{Results and Discussion}

Profile of faculty respondents consisted of faculties at UIN Raden Intan Lampung. The Faculty of Tarbiyah and Teacher Training is the faculty with the most respondents in this study, totaling 319 people (63. 3\%). The Islamic Faculty of Economics and Business is the second largest, with 82 people $(6.3 \%)$, followed by the sharia faculty with 37 respondents $(7.3 \%)$ and the Faculty of Da'wah and Communication Studies 36 people (7.1\% ). The Ushuluddin Faculty and the Study of Religion are the fewest respondents in this study, with a total of 30 people $(6 \%)$. Furthermore, the level of self-efficacy and decision making of respondents, as well as correlation analysis, can be seen in table 1 .

Table 1. Correlation between self-efficacy and decision making

\begin{tabular}{ccccccc}
\hline & \multicolumn{2}{c}{ Self-Efficacy } & \multicolumn{2}{c}{ Decision Making } & p & r \\
\cline { 1 - 5 } & N & Percent & N & Percent & & \\
\cline { 1 - 5 } Medium & 183 & 36.3 & 150 & 29.8 & $<0.05$ & 0.628 \\
High & 321 & 63.7 & 354 & 70.2 & $<0.05$ & 0.628 \\
Total & $\mathbf{5 0 4}$ & $\mathbf{1 0 0 . 0}$ & $\mathbf{5 0 4}$ & $\mathbf{1 0 0 . 0}$ & & \\
\cline { 1 - 5 }
\end{tabular}

In table 1, 321 respondents $(63.7 \%)$ were at a high level of self-efficacy, 183 respondents $(36.3 \%)$ were at a moderate level of self-efficacy. Furthermore, the overall decision-making rate of respondents; there are 354 respondents $(70.2 \%)$ have a high level of self-efficacy. And as many as 150 respondents (29.8) are at a moderate level of decision making. For the correlation of respondents' self-efficacy with decision making, it can be seen that the correlation score of 0.628 shows a strong relationship between cell efficacy and respondent decision making. The relationship is based on the results of data analysis showing a positive direction. This means that the higher the respondent's self-efficacy, the higher the respondent's decision-making level. Furthermore, the relationship between these two variables is also very significant, seen from the acquisition of a significant value $<0.05$. Based on the results of research analysis shows that there is a significant positive relationship between selfefficacy and decision-making to continue education at college students at the Raden Intan State Islamic University Lampung, positive means that the higher the college student's self-efficacy, the higher the level of college student decision making

This result is supported by previous research which found high self-efficacy in decision making and commitment in the completion of studies and careers (Jiang, 2016). Jiang's research results show that individuals who have self-efficacy in decision making tend to be more 
committed to education taken, have career planning and goal setting. Besides, self-efficacy owned by individuals can improve self-regulation strategies in learning and strengthen decision-making beliefs. This is in line with research that says the right decision making based on self-confidence and ability will have a significant effect on academic achievement. (Santos, Wang, \& Lewis, 2018).

A study says choosing and preparing to carry out a job is one of the essential tasks in the developmental stage because one's work determines various things in life (Pasaribu, Susanti, \& Hartuti, 2019). Therefore, college students need to prepare matters relating to the selection of education and career. One that can help college students in making themselves to achieve knowledge and job is to have functional self-efficacy. Every college student indeed needs Self-efficacy and confidence in decision making. Not only pursuing academic achievements, but also college students are required to perform other tasks such as completing tasks related to career or organizational responsibilities. The longer the lecture, the higher the perceived responsibility, which must focus on the work of the thesis and think about continuation after completing the study.

One study showed individuals with great problem-solving abilities would feel more confident in their ability to make continuing education and career potential decisions (Bolat \& Odac1, 2017). Bandura revealed that individuals who have high self-efficacy could be more successful in terms of completing a particular job or task compared to individuals who have low self-efficacy (Bandura, 1997). The results of other studies revealed that parental support or influence on one's optimism. If the environment is supportive then individuals tend to be able to see the future positively (Rahayu, 2018). Also, self-efficacy and continuing study decision making can influence career optimism because they are considered to be practical problem-solving strategies, allocating resources, and setting realistic goals. While other studies say that there is a relationship between self-efficacy of continuing study decision making with one's career maturity (Barokah \& Yulianto, 2019).

The decision of college students to choose and continue their education at tertiary institutions is inseparable from college students' beliefs, and also environmental factors that will support their career success in the future. Raden Intan State Islamic University is an Islamic-based tertiary institution, if seen from the Indonesian state, which is predominantly Muslim, Raden Intan State Islamic University has tremendous potential in efforts to develop and increase motivation that is based on the spiritual beliefs (spiritual motivations) of college students.

It is a resource that is expected to improve religiously. Every Muslim college student needs to understand and understand the standards of behavior, religion, norms, moral values, and laws that originate from Islam as the basis for his spiritual motivation in learning and his future career. Islamic views are believed to have perfect teachings (Arifudin, 2017). In it teaches spiritual, moral values that are beneficial to adherents. The messages of Islam can lead a Muslim to have a positive and productive outlook at work. It becomes a guideline for college students to be sure and organize themselves so that they make the right decisions in everything, especially the decision to continue their education and career for the future.

The existence of a positive relationship between self-efficacy and decision-making to continue study in college students, it can be concluded that self-efficacy can affect continuing decision-making on college students. Confidence in self and educational environment factors become the primary role in decision making. The higher the self-efficacy, the higher the person's decision-making ability. With top self-efficacy, college students can have strategies in the form of planning, self-understanding, work assessment and a rational understanding of the goals and decision making about what is desired 


\section{Conclusions and Suggestions}

Based on the results and discussion of the study, it was concluded that there was a significant positive relationship between self-efficacy and decision-making to continue education at college students at Raden Intan State Islamic University, the higher the college student's self-efficacy, the higher the level of college student decision making. With top selfefficacy, college students can have strategies in the form of planning, self-understanding, work assessment, and a rational understanding of the goals and decision making about what is desired.

Advanced researchers are advised to research with different settings, such as qualitative research, to deepen these variables further. Besides, researchers can also add other variables to see the relationship between self-efficacy and decision making.

\section{References}

Arifudin, I. (2017). Integrasi Sains dan Agama serta Implikasinya terhadap Pendidikan Islam. Edukasia Islamika, 161-180.

Asakereh, A., \& Yousofi, N. (2018). Reflective Thinking, Self-Efficacy, Self-Esteem and Academic Achievement of Iranian EFL Students in Higher Education: Is there a Relationship? International Journal of Educational Psychology, 7(1), 68-89.

Bandura, A. (1977). Self-efficacy: toward a unifying theory of behavioral change. Psychological Review, 84(2), 191.

Bandura, A. (1997). Self-efficacy: The exercise of control. Macmillan.

Barokah, N., \& Yulianto, A. (2019). Pengaruh Lingkungan Sekolah, Self Efficacy, dan Status Sosial Ekonomi Orang Tua Terhadap Minat Melanjutkan Pendidikan Tinggi Dengan Prestasi Belajar sebagai Variabel Mediasi. Economic Education Analysis Journal, 8(2), 434-452.

Bolat, N., \& Odac1, H. (2017). High school final year students' career decision-making selfefficacy, attachment styles and gender role orientations. Current Psychology, 36(2), 252259.

Chiesa, R., Massei, F., \& Guglielmi, D. (2016). Career decision-making self-efficacy change in Italian high school students. Journal of Counseling \& Development, 94(2), 210-224.

Frazier, R., Bendixen, L. D., \& Hoskins, W. J. (2019). Exploring The Role Of Self-Efficacy In Prospective Teachers'career Decision-Making. Journal of Ethnographic \& Qualitative Research, 13(4).

Gati, I., Levin, N., \& Landman-Tal, S. (2019). Decision-making models and career guidance. In International handbook of career guidance (pp. 115-145). Springer.

Guan, P., Capezio, A., Restubog, S. L. D., Read, S., Lajom, J. A. L., \& Li, M. (2016). The role of traditionality in the relationships among parental support, career decision-making selfefficacy and career adaptability. Journal of Vocational Behavior, 94, 114-123.

Jiang, Z. (2016). Emotional intelligence and career decision-making self-efficacy: Mediating roles of goal commitment and professional commitment. Journal of Employment Counseling, 53(1), 30-47.

Kirdök, O., \& Harman, E. (2018). High School Students' Career Decision-Making Difficulties According to Locus of Control. Universal Journal of Educational Research, 6(2), 242248.

Lent, R. W., Ezeofor, I., Morrison, M. A., Penn, L. T., \& Ireland, G. W. (2016). Applying the 
social cognitive model of career self-management to career exploration and decisionmaking. Journal of Vocational Behavior, 93, 47-57.

Liu, W., Dong, Y., Chiclana, F., Cabrerizo, F. J., \& Herrera-Viedma, E. (2017). Group decision-making based on heterogeneous preference relations with self-confidence. Fuzzy Optimization and Decision Making, 16(4), 429-447.

Negru-Subtirica, O., \& Pop, E. I. (2016). Longitudinal links between career adaptability and academic achievement in adolescence. Journal of Vocational Behavior, 93, 163-170.

Pasaribu, V. L. D., Susanti, F., \& Hartuti, E. T. K. (2019). Memotivasi Siswa dan Siswi SMK Letris Indonesia di Dalam Menentukan Pilihan Untuk Melanjutkan Pendidikan Atau Bekerja Setelah Lulus Sekolah. Jurnal Pengabdian Dharma Laksana, 1(2), 161-172.

Rahayu, A. (2018). Hubungan dukungan sosial dan konsep diri dengan penyesuaian diri remaja kelas X SMA Angkasa I Jakarta. IKRA-ITH HUMANIORA: Jurnal Sosial Dan Humaniora, 2(2), 75-81.

Rustika, I. M. (2012). Efikasi Diri: Tinjauan Teori Albert Bandura. Buletin Psikologi, 20(1-2), 18-25. https://doi.org/10.22146/bpsi.11945

Santos, A., Wang, W., \& Lewis, J. (2018). Emotional intelligence and career decision-making difficulties: The mediating role of career decision self-efficacy. Journal of Vocational Behavior, 107, 295-309.

Sari, N. K. (2020). Dinamika Perkembangan Spiritualitas dan Relevansinya Terhadap Pendidikan Islam. Tadbir: Jurnal Manajemen Pendidikan Islam, 8(1), 53-65.

Schunk, D. H., \& DiBenedetto, M. K. (2016). Self-efficacy theory in education. Handbook of Motivation at School, 2, 34-54.

Whiston, S. C., Li, Y., Mitts, N. G., \& Wright, L. (2017). Effectiveness of career choice interventions: A meta-analytic replication and extension. Journal of Vocational Behavior, $100,175-184$. 